\title{
HOGYAN VEZET EL A TUDÁS LEBECSÜLÉSE AZ OKTATÁS LEBECSÜLÉSÉHEZ
}

\section{HOW THE DERISION OF KNOWLEDGE LEADS TO THE DERISION OF EDUCATION}

\author{
Czeglédi Csaba \\ kandidátus, Eszterházy Károly Egyetem \\ czegledi.csaba@uni-eszterhazy.hu
}

\section{ÖSSZEFOGLALÁS}

A dolgozat a tudást veszi védelmébe. Miért szorul a tudás védelemre, amikor sokunk számára triviális igazságnak tűnik, hogy a tudás jó dolog, a tudatlanság pedig rossz dolog? Az ok egyszerủ és meglepő: e triviális igazságot egyre többen tagadják. Ennél is meglepőbb, hogy a tudás elleni támadások újabban a tanárképzés világából érkeznek. A dolgozat rámutat az ún. kompetenciaalapú oktatás és tanárképzés néhány alapvető félreértésére, és lerántja a leplet a reflektív gyakorlat nevet viselő elméletellenes tanárképzési doktrínáról. Rámutat arra, hogy e tudásellenes doktrína inkoherens, áltudományos és összeegyeztethetetlen azzal az egyébként koherens eszmerendszerrel, amelyből elméleti indokoltságát sikertelenül kísérli meg levezetni.

\section{ABSTRACT}

The paper is written in defense of knowledge. Why does knowledge need to be defended when many of us consider it a truism that knowledge is good and ignorance is bad? The reason is simple and surprising: an increasing number of people deny this truism. Even more surprisingly, knowledge has recently come under attack from within the world of teacher education. The paper identifies some of the fundamental misunderstandings underlying what is called competence-based teaching and teacher education, and exposes the incoherence of an anti-theoretical teacher educational doctrine called reflective practice, demonstrating how it fails in its pseudoscientific attempt to derive theoretical justification from what is otherwise a coherent system of ideas, with which, however, it is inconsistent.

Kulcsszavak: tudás, kompetencia, tanítás, tanárképzés, reflektív gyakorlat

Keywords: knowledge, competence, education, teacher education, reflective practice 


\section{NÉPI ISMERETELMÉLET ÉS NÉPI METAPEDAGÓGIA}

Alább a tudás védelmére kelek. Közvetve pedig az oktatás, a tanárképzés, a tanárok, végső soron pedig az iskolában tanuló diákok védelmére. Nehéz eldönteni, hogy ha valaki védelmébe veszi a tudást, az azért kínos-e inkább, mert már önmagában értelmetlenség, vagy csupán fölöslegessége okán bírálható, mert a tézis, amelyet védelmébe vesz, triviális igazság. Mindkettőt készséggel vállalom.

A tudás védelmére kelni azért értelmetlenség, mert ez olyan, mintha egy csillagász a Napot, egy biológus pedig a DNS-t magasztalná. Nem teszik, egyrészt mert fel sem merül a kérdés, hogy ,jó-e vagy nem”, hogy ez is, az is létezik, és hogy olyan, amilyen, másrészt mert egyiket sem érte támadás vagy bírálat (hiszen az értelmetlenség lett volna). Meglepő módon, más a helyzet a tudással. Azt bírálatok és egyre erőteljesebb támadások érik. Ezek olykor a legváratlanabb irányból érkeznek. Hasonló a helyzet a jövő tanárainak oktatásával. Vannak, akik úgy vélik, hogy a hagyományos egyetemi tanárképzésre egyáltalán nincs is szükség. Fő érvük az, hogy az ott elsajátítható „elméleti tudások” nemigen hasznosíthatók a tanítás gyakorlatában, mert a tanításhoz „gyakorlati tudásra” van szüksége a tanárnak (bármit jelentsen is ez).

Azt a triviális igazságot, hogy a tudás önmagában érték, nem kevesen és nem akárkik komolyan kétségbe vonják manapság. Mivel sok forog kockán, hiszen a tanulók tudása és az iskolában eltöltött - években mérhető - idejének a minősége a tét, a triviális tézis védelemre szorul. Valójában ennél is nagyobb a tét, de ezt most tegyük félre.

Azoknak, akik ismerik Pléh Csaba Hogy vezet el a bölcsészet lenézése a tudás lenézéséhez? címü előadását (Pléh, 2014, 668-672.) - és most már azoknak is, akik nem -, azonnal szembetünhet a két dolgozat címe közötti hasonlóság. Ez nem a véletlen müve. A tudás mellett kardoskodva azért is hasznos nyilvánvalóvá tennem a kettőnk mondanivalója közötti gondolati rokonságot, mert támaszkodom is rá. Pléh Csabának az alábbi érvelésre nézve leginkább releváns mondanivalója röviden így foglalható össze: a tudás nemcsak önmagában érték, hanem emberi mivoltunk lényegéhez tartozik, mert ,az ember természeténél fogva elméletalkotó és elmélettesztelö lény" (Pléh, 2014, 672.). Ezt egyebütt azzal egészíti ki, hogy a tudás öröm (Pléh, 2017).

Mondhatnám, ott folytatom, ahol ö befejezte: az ő konklúziója az én egyik premisszám. Helyes, ha már most megjegyzem, hogy egyik triviális mondanivalóm egyszerüen az, hogy mindenféle iskola jól teszi, ha az imént idézett konklúziókat észben és tiszteletben tartja. Magától értődőnek tekintem, hogy az iskolai oktatás - minden szinten, beleértve az egyetemi oktatást - jól teszi, ha számol azzal is, hogy a diákok akkor sem tudnák leállítani folytonos magyarázóelmélet-alkotó és -tesztelő kognitív munkájukat (vagy játékukat), ha akarnák, és azzal is, hogy ebben örömüket lelik. 
Az az iskola, amelyik számol az imént említett körülményekkel, nem tiltja, hanem megengedi a diákjainak, hogy folytassák elméletalkotó játékukat, és nem bünteti, hanem támogatja öket ebben is és abban is, hogy értőn és kritikusan fogadják mások magyarázó elméleteit. Az ilyen iskola nemcsak nem veszi zokon, hanem kifejezetten támogatja a diákokat abban is, hogy ne higgyenek el semmit anélkül, hogy jó okuk lenne rá, abból, amit a tankönyveikben (vagy máshol) olvasnak, és a tanáraiktól (vagy másoktól) hallanak. Az ilyen iskola annak megértésében is erősíti és segíti a diákjait, hogy a puszta tény, hogy egy állítás benne van a tankönyvben vagy elhangzott az órán, nem elég jó ok arra, hogy igaznak tekintsék, és magukévá is tegyék. Az ilyen iskola nemcsak az érvelés, az igazolás, a bizonyítás, a világos és egyértelmủ beszéd jelentőségének megértésében, hanem mindezek gyakorlásában is támogatja a diákjait. Az ilyen iskola segíti a diákjait abban, hogy megértsék, és abban is, hogy gyakorolják, hogy miből mi következik és mi nem, illetve hogy mi miből következik és miből nem.

Bár mindez magától értődik, mégis egyre gyakrabban és egyre szembetűnőbben mutatkoznak meg az iskolában és az azt körülvevő világban - amelybe beletartozik az iskolai tanárokat képző intézmények és szakemberek világa is - annak a jelei, hogy az említett trivialitásokat sem észben, sem tiszteletben tartani nem mindenkinek sikerül. Ami az utóbbit illeti, épp ellenkezőleg: respektus helyett egyre hevesebb támadások érik a tudást.

Az nem meglepő, hogy némely diák és sok, a megismerés, a tanulás és a tanítás kérdéseiben tájékozatlan laikus felnőtt gyanakvással és elégedetlenséggel tekint némely hagyományos iskolai tantárgyra - például a fizikára vagy a kémiára -, mert úgy gondolja, hogy annak, amit például a kolloid rendszerek viselkedésével vagy az endoterm oxidációval kapcsolatban elsajátíthat(ott), aligha veszi hasznát a gyakorlatban. Nem meglepö, hogy ilyen haszonelvü meggondolások miatt sokan kétségbe vonják az effélék tanításának indokoltságát is. Az viszont már figyelemre méltó, ha nemcsak a laikusok, hanem a hozzáértők szakmai világából is éri - nemcsak célpontjában, hanem érvelésében is - hasonló támadás a tudást.

Egy laikusnak nem hányjuk a szemére, ha nem tesz lényeges különbséget egy általános vagy középiskola és például egy autósiskola között. Egy autósiskolától indokoltan várjuk el, hogy oktatói ne csupán előadásokat tartsanak a KRESZ szabályairól és a belső égésủ motorok müködéséről stb., hanem tanítsanak meg bennünket autót vezetni. Nem érjük be azzal, hogy mindent megértettünk az autónkat hajtó hőerőgép müködéséről, sőt, talán nem is tartunk erre igényt. Elsősorban azt várjuk el, hogy a tanfolyam végeztével képesek legyünk autót vezetni, és szokásos körülmények között közlekedni vele. Azaz azt várjuk el egy autósiskolától, hogy hasznos, a gyakorlatban alkalmazható tudást segítsen elsajátítani.

Egy laikust nem hibáztatunk azért az induktív általánosításért, amely ugyanezt várja el bármely egyetemtől is. Az viszont már meglepő, és több figyelmet érdemel, ha a tudományos és oktatási kérdésekben járatos szakemberek és oktatáspo- 
litikai döntéshozók szükebb világában is akad, aki úgy tekint egy kutatóhelyre vagy egyetemre, mint a gyakorlatban hasznosítható tudások létrehozására és tanítására rendeltetett intézményekre. Minél többen csatlakoznak a „Légy nyilvánvalóan hasznos, vagy pusztulj!” jelszó alatt kibontakozó tudomány- és tudásellenes mozgalomhoz, annál nagyobb veszély fenyegeti a tudást, a tudományt és minden iskolát is.

Könnyen bezárulhat a tudatlanság ördögi köre. Ha veszélyben a „haszontalan tudományos tudás", akkor veszélyben az iskola. Ha veszélyben az iskola, akkor veszélyben van mindenféle tudás, a „hasznos gyakorlati tudások” elsajátításának lehetösége is. Ki fogja tanítani a „hasznos tudásokat”, ha nem lesznek olyanok, akik fel vannak vértezve a tudás mibenlétére, a tanulás és megismerés természetére, a racionális gondolkodás szabályaira, korlátaira és buktatóira, a nyelvre, a nyelvi kommunikációra és más efféle hiábavalóságokra vonatkozó haszontalan tudásokkal, amelyek nélkül a tanítás megreked az ösztönös próba-szerencse jellegü társas időtöltés szintjén?

A tudás természetéről való gondolkodást már az is kikényszeríti, ha valaki különbséget kíván tenni az iskolában tanítandó „hasznos tudások” - mára bevett és népszerübb terminussal „kompetenciák” - és a „mihaszna elméleti” tudások között. Valakinek ezt a haszontalan metapedagógiai tisztázást el kell(ene) végeznie ahhoz, hogy az említett tudásdisztinkció egyrészt egyáltalán értelmes, másrészt védhetö is legyen, és végül - egyszersmind legföképp - ahhoz, hogy egy egész metapedagógiát erre a szembeállításra lehessen alapozni. Később még visszatérünk a szóban forgó fogalmak tisztázatlanságából adódó néhány zavarba ejtő és kockázatos fejleményre.

Ha nincs ismeretelmélet és megismeréstudomány, hogy olyan „haszontalan” kérdésekkel foglalkozzon, hogy „Mi a tudás?”, „Hogyan teszünk szert a tudásainkra?”, „Mikor tekintünk egy vélekedést igaznak?”, „Mi különbözteti meg az áltudományt a valódi tudománytól?”, „Mi egy tudományos elmélet rendeltetése?”, „Hogyan lehet azt megítélni, hogy melyik elmélet jobb, mint a versenytársai?”, „Hogyan jönnek létre és egyáltalán miért a tudományok elméletei?” stb., akkor tisztázatlanok maradnak az oktatás legalapvetőbb kérdései: az emberi megismeréssel, a tudással és a tanulással kapcsolatos kérdések. Amilyen mértékben tisztázatlanok a tudás és a tanulás alapkérdései, annak megfelelö mértékben tisztázatlanok maradnak a tanítás alapkérdései is, kezdve mindjárt azzal, hogy mi a célja.

Az eddigiek rövid összefoglalásául a következőket mondhatjuk. A tudás köznapi felfogása különbséget tesz hasznos és haszontalan tudások között - bármit jelentsen is a tudás ,gyakorlati hasznossága”. Nevezzük a tudás e felfogását népi ismeretelméletnek. A népi ismeretelméletben a haszontalan tudás az elmélet szinonimája. Ebből adódóan a népi ismeretelmélet szerint a tudomány maga haszontalan úri huncutság - ha pedig az adófizetők költségén mủveli vagy tanítja valaki, 
akkor mások pénzének pocsékolása, amit a legjobb volna megakadályozni, esetleg megtiltani, hacsak nincs valamilyen mentségük a tudományok müvelöinek és oktatóinak. A nyilvánvaló és egyedüli mentségük az lehet, ha vállalják - vagy legalább azt hazudják -, hogy ök is arra törekszenek, hogy a gyakorlatban hasznosítható tudásokat hozzanak létre $\mathrm{s}$ tanítsanak másoknak, és ezt megpróbálják igazolni is. Nevezzük ezt a tudomány népi metaelméletének, más szóval népi tudományelméletnek.

A népi ismeretelmélet pusztán intuitív alapon tesz különbséget hasznos és haszontalan tudás között, hiszen nincs kidolgozott elképzelése sem arról, hogy mi az ún. gyakorlat, sem arról, hogy mi a tudás, sem arról, hogy milyen viszonyban áll a kettő egymással akkor, amikor a tudás ,alkalmazható a gyakorlatban”, sem arról, hogy egyáltalán mit keres az olyan elméleti megértést megtestesítő tudás minden ember fejében, amelyik csak úgy ott van, minden nyilvánvaló gyakorlati haszon nélkül, sem arról, hogy ez az utóbbi milyen viszonyban van a kompetenciákkal. A kompetencia fogalmával kapcsolatos tisztázatlanságokra még visszatérünk.

Az elméletellenes népi tudásfelfogásból egyenesen adódik az a népi metapedagógiai felfogás, amely szerint mindenféle iskolának, az általános iskolától az egyetemig, ugyanaz az alapvető rendeltetése, mint például egy autósiskoláé: a gyakorlatban alkalmazható hasznos tudásokat kell tanítania.

Ha a népi metapedagógia a népi tudományfelfogást is magáévá teszi, akkor ez egyenesen vezet nemcsak a „hasznos tudások” tanítását elöíró doktrínához, hanem a mihaszna elméletek tanításának tiltásához, illetve ezek hasznos tudással történő helyettesitéséhez. E népi felfogás szerint, az utóbbi alól csak azzal mentheti ki magát egy iskola, egy tantárgy vagy egyetemi szak, ha igazolni tudja, hogy a tanítani kívánt elméletek ,a gyakorlatban hasznosíthatók”.

Ezért, ha a népi metapedagógia leszivárog az ún. tantárgy-pedagógiák szintjére, és következetesen érvényt szerez magának, akkor az olyan - a diákok által legkevésbé kedvelt - tantárgyak esetében, mint a fizika és a kémia (Chrappán, 2017) vagy önmaga cáfolatába torkollik, vagy hazugságra kényszerül. Az előbbi azzal a következménnyel járna, hogy az önellentmondás felszámolása érdekében meg kellene szüntetni az említett - és minden hozzájuk hasonló haszontalan elméleti - tantárgy oktatását. Az utóbbi pedig elkerülhetetlenül a diákok lenézésével, egyszersmind az oktatás és az iskola önlejáratásával jár együtt. Tapintatosan fogalmazva, alábecsüli a diákok intellektuális képességeit - egyszersmind önmagát és az oktatást járatja le - az, aki például a newtoni mechanika hasznosságát a háztartásban és a ház körül adódó teendőkre hivatkozva kísérli meg elhitetni a tanulókkal.

Ehelyett érdemes volna megkockáztatni az őszinteséget. A tudományról mindenki megtudhatná, hogy egyetlen tudósnak sincs - és nem is kell, hogy legyen sokkal jobb válasza arra a kérdésre, hogy miért törekszik éppen annak a mélyebb 
megértésére, amit kutat, annál, amit az anekdota szerint a legendás brit hegymászó, George Mallory válaszolt, amikor megkérdezték töle, hogy miért akar felmászni az Everest csúcsára: „Azért, mert ott van.” Hasonló módon, bátran elárulhatnánk a diákoknak is és az ő szüleiknek is, hogy szerintünk nem azért jó fizikát, kémiát vagy anyanyelvünk nyelvtanát tanulni, mert gyakorlati hasznunk származik belöle, hanem azért, hogy minél jobban megértsük, hogy mi folyik a körülöttünk lévő világban meg a saját fejünkben.

A nyelvtudományt mintegy hatvan évvel ezelőtt forradalmasító, idén kilencvenéves Noam Chomsky nem azért tanult nyelvészetet az egyetemen, és nem azért írt több tucatnyi könyvet a nyelv természetéről és szerkezetéről, hogy jobban tudjon és beszéljen az anyanyelvén. Ha azért tanult és írt volna, most roppant csalódottnak kellene lennie, mert ma sem tud jobban angolul, mint bármelyik unokája.

Az önmagáért való megértést kárhoztató népi tudományfelfogás emberi mivoltunk lényegéhez tartozó kognitív képességeinket kárhoztatja. Ez a szó szerint embertelen felfogás csupán azért nem sodor komoly veszélybe minden mihaszna tudóst és kutatóintézetet, mert szerencsére nem akad épelméjü ember, aki ennek következetesen érvényt kívánna és tudna szerezni. Meglepő, egyszersmind sajnálatos módon ugyanez nem mondható el az oktatás világáról. A tanárképzést, az oktatást és végső soron a diákokat veszélyeztető, súlyos félreértéseken alapuló népi metapedagógiai forgatókönyv megvalósulása már elkezdődött (Lawes, 2004).

\section{TUDÁS- ÉS ELMÉLETELLENESSÉG A TANÁRKÉPZÉS NÉPI METAPEDAGÓGIÁJÁBAN}

A tanárképzők körében egyre népszerübb és egyre hangosabb a népi ismeretelméleten és népi tudományfelfogáson alapuló elméletellenes népi metapedagógia, amely szerint mihaszna elméletek tanítására semmi szükség nincs a tanárképzésben, hiszen azok a gyakorlatban nemigen használhatók (Lawes, 2011). A tanárképzés egyik új elméletellenes „reformpedagógiája” azt a népi bölcsességet teszi hozzá ahhoz a naiv tudáskoncepcióhoz és tudományfelfogáshoz, amelyen alapul, hogy a - bevett terminussal - tanári kompetenciák elsajátításának leghatékonyabb módja maga a gyakorlat, azaz a tanítás. Erre később még visszatérünk.

Sok múlik azon, hogy ki mit ért ebben a kontextusban (és egyáltalán) „,kompetenciákon". Részben a kompetenciafogalom lehetséges értelmezéseitől függ például, hogy hogyan torkollik a tanárképzés elméletellenes doktrínája menthetetlenül inkoherenciába, vagy pedig - ami ezzel egyenértékü - kiderül róla, hogy védhetetlen dogma.

Bár nem ez a megfelelö hely és alkalom a kompetencia fogalmának kimerítő tisztázására, néhány megjegyzést érdemes tenni ezzel kapcsolatban. Legelőször is azt célszerü konstatálni, hogy a pedagógia kompetenciafogalma tisztázatlan. 
Neveléstudományi szakértők között alig van egyetértés abban, hogy mi a fogalom tartalma. Ezért esetleges, hogy a különbözö kompetenciaértelmezések közül melyikre épít az a jogszabályként is érvényesített felfogás, amelyik meghatározza, hogy a tanári kompetenciák készletének milyen összetevőkből kell állnia, amely a maga részéről pedig azt szabja meg, hogy a tanárképzésnek milyen oktatási öszszetevőket kell (vagy nem szükséges, s talán nem is szabad) tartalmaznia.

A félszegen sugalmazott, de nyíltan a magát mégoly gyakorlatorientáltnak nevező tanárképzési metapedagógia által sem vállalt szüken értelmezett kompetenciafogalom - amely szerint a kompetencia a (tisztázatlan értelmü) „gyakorlati tudás" szinonimája - nyilvánvalóan az elméleti tudás értékének tagadásába torkollik. Mivel az elméleti tudások relevanciáját a kompetenciaalapú tanárképzési metapedagógia nyíltan nem, csak burkoltan kívánja tagadni, e kellemetlen következmény elleni védekezésül, a „kompetenciaalapú tanárképzési modell” inkább az inkoherens és semmitmondóan tág kompetenciaértelmezést mutatja fel, ami viszont azért nem nyújt védelmet, mert még több kellemetlen következménnyel jár.

Amint arra Nahalka István $(2009,55$.) rámutat, a pedagógiában legelterjedtebb, tőle kölcsönözött kifejezéssel „eklektikus” felfogás, amely szerint a kompetencia „képességeknek, ismereteknek és attitüdöknek a rendszere... az égvilágon semmit nem mond" a kompetencia valódi mibenlétéről. Pusztán attól, hogy a tág kompetenciaértelmezést választó tanárképzési koncepció azzal a követeléssel lép fel, hogy az ismeretek, képességek és attitüdök egyetlen „kompetenciának” nevezett rendszert alkotnak, ezek az „összetevők” nem szerveződnek olyan koherens és autonóm rendszerré, amely megkövetelné, hogy saját jogán „kompetencia” néven elismerjük. Az ilyen törekvések nem segítik a kompetencia és a vele rokon fogalmak tisztázását, hanem épp ellenkezőleg: még zavarosabbá teszik azt. Kellö indoklás híján, a tágan értelmezett „kompetencia” megmarad elméleti jelentőség nélküli esetleges deskriptív terminusnak, az általa jelölt koncepció pedig véleménynek, amelyben néhányan akár osztozhatnak is. De nem számít, hányan vallják ugyanazt, mert pusztán az egyetértés nem teszi e felfogást sem koherensebbé, sem indokoltabbá.

Az önkényesen kitágított kompetenciafogalom egyik kellemetlen következményként azt a vállalhatatlan nézetet kényszeríti a magát továbbra is gyakorlatorientáltnak tekintő hiedelemrendszerre, hogy a „gyakorlatban,” a tanítási tevékenység gyakorlása révén nemcsak szűken vett „gyakorlati tudások”, hanem megértésszerü tudások is elsajátíthatók (amelyeket kissé árulkodó és önleleplező módon szívesebben nevez ismereteknek, mint akár tudásnak, akár megértésnek). Ez olyan, mintha nehéz böröndök rendszeres cipelésétől azt várnánk, hogy pusztán az elegendően gyakori kitartó cipekedés révén egyre jobban megértjük a gravitáció természetét; sőt mélyebben, mint ha a gravitáció létezö és hozzáférhetö magyarázó elméletei közül valamelyiket tanulmányoznánk. E felfogás szélsőséges változatára alább még visszatérünk. 
Érdemes azt is felidézni, hogy legalább az ismeretelméletben és a megismeréstudományban közhelyszámba megy, hogy a tudás nem a kompetenciának alárendelt fogalom, hanem épp fordítva: a kompetencia a tudás egyik fajtája, amelyet olykor képességnek vagy képesség-tudásnak is neveznek (Forrai, 2014; Pléh, 2017). Az utóbbit legalább Gilbert Ryle (1949) óta szembeállítjuk a deklaratív (tudni AZT, hogy..., angolul knowing that) tudással. Az emezzel szembeállított képesség-tudást (tudni, HOGYAN, angolul knowing how) másként procedurális tudásnak szoktuk hívni. Mást és másként tudunk, amikor tudjuk (AZT), hogy Magyarország fővárosa Budapest, mint amit és ahogy tudunk, amikor tudjuk, HOGYAN lehet/kell biciklizni, vagy más szavakkal: amikor tudunk biciklizni.

Hasznos lehet még hozzátenni, hogy - legalábbis az erős megismeréstudományi, sőt biológiai elkötelezettségü modern generatív nyelvtudományban létezik a kompetenciának az imént említetteknél szükebb felfogása is. E felfogás szerint a kompetencia ugyan procedurális természetü tudás, s ezért nyilvánvalóan különbözik a deklaratív tudástól, de nem azonos az olyan knowing how típusú képesség-tudással sem, mint a biciklizni tudás, hanem a tudásnak egy harmadik fajtáját képviseli, amelyiket Noam Chomsky (2015) a knowledge of kifejezéssel különbözteti meg a másik kettőtől, és ebbe a kategóriába sorolja az ember nyelvtudását, azaz nyelvi kompetenciáját.

A kompetenciafogalom különféle pedagógiai értelmezései között sem igen találunk olyat, amelyik nyilvánvalóan a kompetencia fogalma alá sorolná a magyarázó elméletekben megtestesülő megértés típusú tudást (Allwright, 1999). Mivel a tanítás kompetenciaalapú felfogása kizárólag kompetenciák terminusaiban fejezi ki a tanulni és tanítani való tartalmakat, a megértés - nem meglepő módon - szóba sem kerül. Ugyanez érvényes az ebben a szellemben fogant tanárképzésre is, hiszen e felfogás szerint - csupán a következetesség okán is - a tanárképzésnek ugyanennyire kompetenciaalapúnak kell lennie. Lehet, hogy a tanárképzés kompetenciaalapú metapedagógiája szerint a tanároknak nem szükséges megérteniük semmit?

Nem tudni, hogy a tudás és a megértés csupán figyelmetlenségből nincsenek megemlítve a kompetencia egyébként nyilvánvalóan falánk megfogalmazásában, vagy azért, mert e mögött mégiscsak az a pedagógiai sejtés húzódik meg, hogy nem a tudás a kompetencia egyik válfaja, hanem fordítva, és hogy a megértés nem a kompetencia egyik fajtája, hanem a tudásé. A fejünkben létrehozott magyarázó elméletek sem maguk nem tekintendők kompetenciának, sem nem részei semmilyen kompetenciának, de minden magyarázó elmélet része birtokosa tág értelemben vett tudásának.

A deklaratív típusú megértés és a procedurális természetü kompetencia megkülönböztetéséből természetesen nem következik, hogy magyarázó elméleteink és kompetenciáink ne léphetnének egymással interakcióra. Épp ellenkezőleg. Az volna meglepö, ha kompetenciáink teljesen el volnának szigetelve a közelükben könnyen hozzáférhető magyarázó elméletektől az elménkben. Nyelvi kompeten- 
ciánk például lépten-nyomon interakcióra lép többé-kevésbé kidolgozott világmodellünkkel. Enélkül értelmezhetetlenek volnának az olyan egyszerü mondataink is, mint például az, hogy „A Föld a Nap körül kering”.

A deklaratív, a világot leképező és magyarázó tudás jelentőségével és látszólag a gyakorlati boldogulásunkra specializálódott procedurális tudásainkhoz füzödő viszonyával kapcsolatban azt fontos még leszögezni, hogy a szóban forgó tudáskonstrukciós kettősség egyrészt emberi mivoltunk lényegéhez tartozik (Pléh, 2017), másrészt a viselkedéseinket közvetlenül lehetővé tevő kompetenciáink müködésük közben nem csupán hivatkoznak világmodellünkre, hanem függnek is tőle. Nyelvhasználati viselkedésemben például tudnom kell, hol vagyok és kivel beszélek ahhoz, hogy megértsem, s ennek alapján eldöntsem, hogy mit célszerü és helyénvaló mondanom, és mit nem. Fontos ismét hozzátenni, hogy ettől a függőségtől a világmodellem nem válik a nyelvhasználati kompetenciám részévé.

A haszonelvü, az emberi tudás és megismerés alapvető félreértésén alapuló (Pléh, 2017) tanárképzési doktrína egyik fölöttébb zavarba ejtő aspektusa az a tudás- és elméletellenesség, amely laikusoktól nem, de a tanulás és tanítás kérdéseivel hivatásszerüen foglalkozók részéről legalábbis meglepő. Ha maguknak a jövendő tanároknak az oktatása az említett súlyos félreértésekből eredő tudásellenességen alapul, az komoly veszélyt jelent az iskolai tanításra, s végső soron a diákok tanulására és tudására.

Ezért nemcsak váratlan, hanem kínos, ha a tudás elleni legveszélyesebb támadások az iskolát közvetlenül övezö világból, a tanárképzést megreformálni kívánó törekvések harcosaitól érkeznek (Jay-Johnson, 2002; Jones, J. L.-Jones, K. A., 2013). A veszélyt fokozza, hogy mivel a saját jogán értékes tudás nyílt kétségbe vonásának kínosságával maguk az ostromlók is tisztában vannak - ha máshonnan nem, hát annak belátásából vagy legalább sejtéséből, hogy saját tudásuk jelentős része sem állja ki a maguk szabta hasznosság próbáját -, tudásellenes attitüdjüket igyekeznek leplezni, nyíltan pedig tagadni.

A neveléstudományban nagyon kevesen teszik annyira nyilvánvalóvá, mint például Ollé János $(2013,23$.), hogy szerintük az oktatásban ,a legfontosabb érték ma már nem az információ vagy a tudás". Azok, akik ehhez hasonlóan vélekednek a tudásról és az oktatásról, inkább különféle megtévesztő csomagolásba burkolva kísérlik meg elfogadtatni tudásellenes nézeteiket, egyrészt magukkal a tanárokkal, másrészt közvetlenül a tanárképzőkkel s végül, az oktatást körülvevő világban mindazokkal, akiknek több-kevesebb befolyásuk van arra, hogy mi történik egyfelől az iskolában „oktatás-nevelés” címén, másrészt az egyetemeken tanárképzés címén. Az ún. „kompetenciaalapú oktatás” ennek az elméletellenes és ,gyakorlatorientált” oktatási doktrínának az egyik változata (vagy fedőneve), amely mára lényegében teljesen a hatalmába kerítette nem csupán az iskolai oktatást, hanem a tanárképzést is, és nemcsak Magyarországon, hanem másutt is (Lawes, 2004). 


\section{TUDÁSELLENESSÉG ÁLTUDOMÁNYOS KÖNTÖSBEN}

Mégsem a tanítás homályos kompetenciaalapú ideológiája jelenti a legnagyobb veszélyt az iskolai oktatásra és a tanárképzésre. Amikor az oktatás kompetenciaalapú doktrínája a tanítást kompetenciafejlesztésként határozza meg, és ezt szabja egyszersmind az iskolai oktatás feladatául, ha ebben - a bevett, bár meglehetősen önkényes módon - elegendően tágan értelmezi alapvető fogalmát, a kompetenciát, amely nemcsak ,gyakorlati készségeket”, hanem „,ismereteket” is magába foglal, akkor e felfogás legalább megengedi a félszegen ismereteknek nevezett, nem nyilvánvalóan gyakorlati használhatóságot ígérő tudások elsajátításának támogatását az oktatásban.

Arra azért érdemes felfigyelni, hogy ebben a megengedő tanításfelfogásban nyilvánvaló kiegyensúlyozatlanság rejlik a gyakorlat mércéje szerint „hasznos” kompetenciák és az ugyanezen kritérium szerint nem nyilvánvalóan hasznos ismeretek egymáshoz való viszonyában. Egyszerủen szólva, a kompetencialapú tanításfelfogás az előbbiek oktatását feladatul szabja, míg az utóbbiak tanítását megengedi.

Nem nehéz azt sem észrevenni, hogy ez a megengedés nem feltétel nélküli: az a feltétele, hogy az ismeretek legalább többé-kevésbé kimutathatóan támogassák a gyakorlati kompetenciák elsajátítását és fejlődését. Ebből nyilvánvalóan az következik, hogy ez a megengedés nem terjed $k i$ az öncélú, semmilyen kimutatható gyakorlati haszonnal nem járó elméleti tudás, azaz pusztán az önmagáért való megértés elsajátításának támogatására (amely nélkül pedig - emlékeztetöül - a gyakorlati kompetenciák is múködésképtelenek).

Nem meglepö, hogy szakmai körökben az elméletellenesség olykor ennél rafináltabb - $\mathrm{s}$ ezért veszélyesebb - áltudományos köntösben jelenik meg. Ebben a tudományosság látszatát keltő érveléssel kell megpróbálni rávenni a közönséget arra, hogy utasítsa el a tudást - legföképp a mihaszna elméleti tudást - mint az iskola és az oktatás számára legfőbb értéket, és ilyen értékként kizárólag a gyakorlati hasznosságot felmutatni képes kompetenciákat ismerje el.

Ennek a haszonelvü tanítási ideológiának a tanárképzésre érvényesített szélsőséges változata az ún. reflektív gyakorlat doktrínája, amely nemcsak azt hirdeti, hogy a tanárképzés feladata kizárólag a tanítási gyakorlatban közvetlenül hasznosítható tanári kompetenciák elsajátításának elősegítése, hanem azt is vallja, hogy ezeket a gyakorlati tudásokat nem a mihaszna elméletekröl szóló egyetemi előadásokon, hanem a gyakorlatban, valóságos iskolákban végzett tanítási tevékenység során lehet a leghatékonyabban elsajátítani (Jones, J. L.Jones, K. A., 2013).

A tanárképzés e végletesen gyakorlatorientált és elméletellenes modellje e két feltevésből vezeti le azt a konklúzióját, hogy a gyakorlati tanítási kompetenciák elsajátításának legjobb módja az, ha a tanárjelölt mihamarabb elkezd (megpróbál- 
ni) tanítani - lehetőleg az első pillanattól kezdve, bármiféle mihaszna elméletek tanulása helyett. E modell legszélsőségesebb - olykor iskolaalapúnak nevezett változata szerint az egyetemi tanárképzés egyenesen fölösleges, vagy legföljebb az lehet a szerepe, hogy előkészítsen a gyakorlati reflexióra, mert a tanárképzés színtere maga az az iskola, amelyben a tanítani tanuló tanár azért tanít, hogy megtanuljon tanítani, s ezért legjobb, ha az egész folyamat irányitása is ugyanennek az iskolának a kezében van (Brown et al., 2014).

E reflektív gyakorlatorientált tanárképzési modell zavarba ejtő következményeket jósol magára a tanításra nézve. A gyakorlaton alapuló kompetenciaelsajátítás elkerülhetetlenül azt implikálja, hogy addig, amíg a teljesen képzetlen kezdö gyakorló-tanuló tanár gyakorlott tanárrá nem válik, dilettáns módon fog tanítani. Ha ezt a mindenféle szakértelem híján végzett ,tanítást” valóságos iskolában, valóságos diákokkal, valóságos tanórákon teszi, annak nyilvánvalóan kínos, sőt káros következményei lehetnek, amelyeket itt most nem szükséges részletezni. Legyen elég annyi, hogy ha a dilettantizmusa nem is okoz minden esetben súlyos károkat, a tanulók iskolában töltött értékes és soha vissza nem térő idejének legalább egy részét akkor is el fogja vesztegetni. Ennél a diákok többet érdemelnek.

Nem minden fogalmi és logikai bukfenc nélkül, a reflektív gyakorlat tanárképzési doktrínája azzal az igénnyel lép fel, hogy felváltsa a hagyományosan elméleti komponenseket is tartalmazó egyetemi tanárképzést, és magát a gyakorlatot tegye meg a tanárképzés elméletévé (Lawes, 2003).

E doktrína egyre növekvő népszerüségét Donald A. Schönnek (1983) a saját munkájára reflektáló gyakorló szakemberről (a mérnökről, az építészről, a menedzserről, a pszichoterapeutáról és a várostervezőröl) írt könyve alapozta meg, elméleti megalapozását pedig a pragmatista John Deweynak (1933) a reflektív gondolkodásról írott könyvében vélik felfedezni.

A reflektív tanár és a reflektív gyakorlat jellemzésének alapjául a reflektiv gondolkodás fogalma szolgál, amely Dewey meghatározása szerint az „az aktív és kitartó törekvésünk, amely során gondosan ellenörizzük, hogy hiedelmeink és vélelmezett tudásaink mennyiben igazolhatók, és hogy milyen további következtetések adódnak belőlük" (Dewey, 1933, 9.). Ez nem más, mint a bennünket is magában foglaló világ minél jobb megértésére irányuló azon törekvésünk, amely során ellenőrizhető, azaz igazolható vagy cáfolható hipotéziseket konstruálunk, amelyekből belső konzisztenciájuk révén további ellenőrizhető jóslatok adódnak, amelyek ellenőrzése a maga részéről hozzájárulhat a világ megértését megtestesítő magyarázó elméleteink tökéletesítéséhez.

Ezért, ha valaki Dewey reflektív gondolkodás fogalmából kiindulva próbálja deduktív érvelésben levezetni a reflektív gyakorlat elméletellenes tanárképzési doktrínáját, annak vagy a logikát kell kicseleznie, vagy Dewey gondolatait kell meghamisítania, vagy részben elhallgatnia. Ha valamit nem lehet Dewey gyakran 
idézett gondolatából levezetni, az éppen az elméletellenesség. Azért nem, mert - tömören összefoglalva - Dewey felfogásában a reflektív gondolkodás nem más, mint hipotézisalkotás, a megkonstruált elméletek tesztelése, igazolása és szükség szerinti módosítása, majd a módosított elméletek újbóli ellenőrzése, és így tovább. Az igazolhatóságtól eltekintve, akár a tudományfilozófus Karl Popper is mondhatta volna.

Dewey $(1933,276$.$) a tanári szaktudás népszerü félreértéseivel kapcsolatban is$ világosan fogalmaz: „Sajnos... a [tanári] szaktudást olykor... úgy tekintik, mint a cselekvésben alkalmazandó merev eljárási szabályok készletét", holott a tanár elméleti, például pszichológiai tudása nem azonos valamiféle „eljárási szabályok” ismeretével, mai szóval, az ún. gyakorlati tanári kompetenciákkal vagy szakmódszertani ismeretekkel. Ugyanígy óva int a látszólag minden gyakorlati haszon nélküli, tőle kölcsönzött kifejezéssel „puszta elmélet” lebecsülésétől is, amikor hangsúlyozza, hogy a tanár „intellektuális felkészültségének... a túlcsordulásig bőségesnek kell lennie” (uo. 274.), egyebek között azért, mert ahogyan „egy diák különböző tantárgyak tanulója”, ahhoz hasonlóan ,egy tanár a diák elméjének a tanulója" (uo. 275.).

Dewey pár fentebb idézett gondolatából is nyilvánvaló, hogy ő megbecsülte a tudást is, a tanítást is, a tanárt is és a tanulót is. Azt is világossá tette, hogy szerinte ,a tanulás [nem más, mint] gondolkodni tanulás” (uo. 78.). Ezzel szemben, a metapedagógiai retorika szintjén az ö nézeteire alapozott, de azokkal pontról pontra összeegyeztethetetlen reflektív gyakorlat tudás- és elméletellenes tanárképzési doktrínája lenézi a tudást is, a tanítást is, a tanárt is és a tanulót is. Ami a tanár szakos egyetemistákat illeti, őket meg is kívánja fosztani attól, hogy az egyetemen tanulhassanak gondolkodni.

Összefoglalásul, ha hívei s hatalmi pozícióban lévő érvényesítői szerint a reflektív gyakorlat elméletellenes tanárképzési doktrínájának legszilárdabb elméleti alapját Deweynak a tudásra, a tanulásra, a tanításra és a reflektív gondolkodásra vonatkozó nézetei alkotják, akkor e doktrína megalapozatlan, hiszen minden elemében ellentmond annak az eszmerendszernek, amelytől megalapozottságát várja. Dewey (1933) müve a föcíme szerint is arról szól, hogy „Hogyan gondolkodunk"; alcíme szerint pedig ezenkívül arról, hogy ez a hipotézisalkotó „reflektív gondolkodásunk hogyan kapcsolódik az oktatás folyamatához”. Dewey gondolkodásra és tanításra vonatkozó mondanivalója nemhogy alkalmatlan arra, hogy a reflektív gyakorlat elméletellenes tanárképzési doktrínáját megalapozza, hanem akár azt is mondhatnánk, hogy a kívánt célra ennél alkalmatlanabb forrást nehezen találhatna e magát gyakorlatorientáltnak tekintő doktrína. Igaz, a tanárképzés elméletellenes doktrínáját ellentmondásmentesen semmilyen elmélettel nem lehet megalapozni. Zavarba ejtő, ha a több évezredes hagyomány és józan megfontolás szerint a tudás elmélyítésének és gyarapításának elősegítésére létrehozott iskolát az ott tanító tanárok felkészítését vállaló 
tanárképzés kívánja eredeti és ma is érvényes céljától eltántorítani. Az pedig egyenesen kétségbeejtő, ha bárki az elméleti tájékozottságot és megalapozást nyújtó hagyományos egyetemi tanárképzést akár burkoltan, akár nyíltan a dilettantizmust preferálva meg kívánja szüntetni. A reflektív gyakorlat tudásellenes ostora a legvégén az iskolásokon csattan.

\section{IRODALOM}

Allwright, D. (1999): Am I Now, Have I Ever Been, and Could I Ever Be - A 'Developer'? Novelty, 6, 1, 4-19. http://ludens.elte.hu/ deal/pages/novelty/htm2/vol61/allwri.htm

Brown, T. - Rowley, H. - Smith, K. (2014): Rethinking Research in Teacher Education. British Journal of Educational Studies, 62, 3, 281-296. DOI: 10.1080/00071005.2014.955080, https:// www.tandfonline.com/doi/full/10.1080/00071005.2014.955080

Chomsky, N. (2015): What Kind of Creatures Are We? New York: Columbia University Press (magyarul: Miféle teremtmények vagyunk? [ford. Kisantal Tamás] Budapest: Kossuth Kiadó, 2018)

Chrappán M. (2017): A természettudományi tárgyak helyzete és elfogadottsága a közoktatásban. Magyar Tudomány, 11, 1352-1368. DOI: 10.1556/2065.178.2017.11.3, https://mersz.hu/hivatkozas/matud_40\#matud_40

Dewey, J. (1933): How We Think: A Restatement of the Relation of Reflective Thinking to the Educative Process. Boston: DC Heath and Company, https://archive.org/details/howwethinkrestat00dewerich

Forrai G. (2014): Kortárs nézetek a tudásról. Budapest: L'Harmattan Kiadó

Jay, J. K. - Johnson, K. L. (2002): Capturing Complexity: A Typology of Reflective Practice for Teacher Education. Teaching and Teacher Education, 18, 73-85. DOI: 10.1016/S0742051X(01)00051-8, https://bit.ly/2tlYMEb

Jones, J. L. - Jones, K. A. (2013): Teaching Reflective Practice: Implementation in the Teacher-Education Setting. The Teacher Educator, 48, 73-85. DOI: 10.1080/08878730.2012.740153, https:// bit.ly/2JXqZbu

Lawes, S. (2003): What, When, How and Why? Theory and Foreign Language Teaching. Language Learning Journal, 28, 22-28. DOI: 10.1080/09571730385200171

Lawes, S. (2004): The End of Theory? A Comparative Study of the Decline of Educational Theory and Professional Knowledge in Modern Foreign Languages Teacher Education in England and France. PhD diss. London: Institute of Education, University of London, http://discovery.ucl. ac.uk/10007418/

Lawes, S. (2011): Who Will Defend Teacher Education? In: In Defence of Teacher Education, SCETT, 24-25. http://www.scett.org.uk/media/3583/in_defence_of_teacher_education_ scett_march_2011.pdf

Nahalka I. (2009): A tanulás tudománya. Pedagógusképzés, 2-3, 37-59. https://issuu.com/heju/ docs/2009_2-3

Ollé J. (2013): Pedagógiai kultúra az információs társadalomban. In: Ollé J. - Papp-Danka A. Lévai D. et al. (szerk.): Oktatásinformatikai módszerek. Tanitás és tanulás az információs társadalomban. Budapest: ELTE Eötvös Kiadó, 9-29. http://www.eltereader.hu/media/2013/11/ Olle2_okt-inform_READER.pdf 
Pléh Cs. (2014): Hogy vezet el a bölcsészet lenézése a tudás lenézéséhez? Magyar Tudomány, 6, 668-672. http://www.matud.iif.hu/2014/06/06.htm

Pléh Cs. (2017): Tudásfajták a kognitív kutatásban, az iskolában és a köznapokban. Magyar Tudomány, 178, 11, 1387-1398. DOI: 10.1556/2065.178.2017.11.6, https://mersz.hu/hivatkozas/matud_43\#matud_43

Ryle, G. (1949): The Concept of Mind. London: Hutchinson (magyarul: A szellem fogalma [ford. Altrichter F.]. Budapest: Osiris Kiadó, 1999)

Schön, D. A. (1983): The Reflective Practitioner: How Professionals Think in Action. New York: Basic Books 